UDC 347.1

LBC 67.404

\title{
THE DEVELOPMENT OF THE INSTITUTE OF PROTECTION OF VIOLATED RIGHTS IN HISTORICAL RETROSPECT
}

\author{
Teimuraz L. Pagava \\ Volgograd Institute of Management - Branch of Russian Presidential Academy of National Economy \\ and Public Administration, Volgograd, Russian Federation
}

Introduction: today the institution of protection of civil rights is one of the main institutions of law. Its object matter manifests itself in the fact that this institution contributed to the defense of the property interests of citizens, both in modern Russia and in the Soviet and pre-revolutionary period. Studying this institution, first of all, it is necessary to understand not only its object matter, but also the features of its application when there is a violation of property rights. Understanding it is a key tool to investigate its nature and the characteristics of civil law consequences, as well as other cases that arise in the application of this institution in relation to the violated rights and freedoms. In this regard, the author set a goal - to investigate the historical way of forming and developing the institution of protection of property rights since the adoption of the Code of Laws "Russkaya Pravda" up to the current Civil Code of the Russian Federation. Methods: the methodological framework for this work is a set of methods such as historical law, system, analysis, and the comparative law method. Results: in the course of the study, the author's viewpoint is based on the legislative acts that have been in force throughout the time period researched in this work, as well as on the viewpoints of the representatives of scientific thought. In this paper the author investigates the institution of protection of violated rights. The main emphasis in this work is on property rights, since the legal regulation of property has been provided since the adoption of the first normative act in Russia - the Code of Laws "Russkaya Pravda". Conclusions: in the course of the study there are reviewed such regulations as the Code of Laws "Russkaya Pravda", Law Book of 1497 and 1550, Council Code of 1649, and others. During the research it is established that this institution was used both for protecting property rights (vindicatory actions), and for protecting the rights of the owners of the property, owned it in good faith as their own. It is established that since the time of the Code of Laws "Russkaya Pravda", the owner of the property has had the right to compensation for violating his property rights, and testimony and written documents have been able to act as the evidence of a transaction in a court of law.

Key words: methods of protection, property relations, property, forms of protection, normative acts of antiquity.

УДК 347.1

ББК 67.404

\section{РАЗВИТИЕ ИНСТИТУТА ЗАЩИТЫ НАРУШЕННЫХ ПРАВ В ИСТОРИЧЕСКОЙ РЕТРОСПЕКТИВЕ}

\author{
Теймураз Леванович Пагава
}

Волгоградский институт управления - филиал Российской академии народного хозяйства и государственной службы при Президенте Российской Федерации, г. Волгоград, Российская Федерация

Введение: институт защиты гражданских прав на сегодняшний день представляет собой одни из главных институтов права. Его назначение проявляется в том, что данный институт способствовал отстаиванию имущественных интересов граждан как в современной России, так и в советском и дореволюционном периоде. Исследуя данный институт, в первую очередь следует понять не только его назначение, но и особенности его применения при нарушении имущественных прав. Понимание его является ключевым инструментом, позволяющим исследовать его природу и характерные черты гражданско-правовых последствий, а также иные случаи, которые возникают при применении данного института в отношении нарушенных прав и 
свобод. В связи с этим автором поставлена цель - исследовать исторический путь становления и развития института защиты имущественных прав начиная со времен принятия свода законов «Русская Правда» вплоть до действующего Гражданского кодекса Российской Федерации. Методы: методологическую основу данной работы составляют совокупность таких методов, как историко-правовой, системный, анализ, а также сравнительно-правовой метод. Результаты: в ходе исследования выработанная автором позиция основана на законодательных актах, действующих на протяжении всего временного периода, исследованного в данной работе, а также на позицию представителей научной мысли. В данной работе автор исследует институт защиты нарушенных прав. Основной акцент в данной работе делается на имущественные права, поскольку правовое регулирование собственности было предусмотрено со времен принятия на Руси первого нормативного акта - свода законов «Русская Правда». Выводы: в ходе исследования были проанализированы такие нормативные акты, как свод законов «Русская Правда», Судебники 1497 г. и 1550 г., Соборное уложение 1649 г. и др. В ходе исследования было установлено, что данный институт применялся как в защиту прав собственников (виндикационные иски), так и в защиту прав собственников имущества, добросовестно владевших им как своим. Установлено, что начиная со времен действия свода законов «Русская Правда» собственник имущества имел право на компенсацию при нарушении его имущественных прав, а в качестве доказательств совершения сделки в суде могли выступать как свидетельские показания, так и письменные документы.

Ключевые слова: способы защиты, имущественные отношения, собственность, формы защиты, нормативные акты древности.

\section{Введение}

Основу формирования представлений о защите можно усмотреть еще в обычаях и писаном праве древних славян. Именно в этот период в Киевской Руси происходит зарождение форм защиты нарушенных прав, когда функции судьи осуществляли как князь, так и община, руководствующаяся нормами обычного права (правовые обычаи). Несмотря на это, за гражданами сохранялось право на розыск утерянного имущества и предъявления требований об истребовании имущества из чужого незаконного владения (самозащита прав), а также требований о компенсации за нарушение прав собственника.

\section{Законодательство Древней Руси о защите имущественных прав}

Позднее, в ходе усиления княжеской власти, на смену правовым обычаям на Руси приходит первый писанный нормативный акт свод законов «Русская Правда». Примером защиты прав пострадавшей стороны является ст. 37 Русской Правды (пространная редакция), в которой предусмотрено, что если кто-либо приобретет на рынке что-нибудь украденное, то он обязуется привлечь в качестве свидетелей двух свободных людей или одного сборщика пошлин в доказательство правомерности приобретения товара [7, с. 13].
При этом в данном акте предусматривалось только 3 первоначальных способа возникновения права собственности, несмотря на то, что договорные отношения в то время также существовали:

1) договор; по наследству;

2) давность владения;

3) приплод (рождение от скота или от рабыни).

Также следует отметить, что Русская Правда уже предусматривала такой способ защиты, как изъятие имущества из чужого незаконного владения. По своей сути оно представляло собой виндикационное требование не владеющего собственника к владеющему несобственнику о возврате незаконно присвоенной вещи. Русская Правда может считаться (с определенной оговоркой) первым нормативным актом, предусматривающим виндикационное требование истца к ответчику об истребовании имущества, при этом истец, согласно ст. 34 Русской Правды [7, с. 12], имел право на компенсацию в размере 3 гривен.

Анализируя данный нормативный акт, следует обратить внимание, что в качестве доказательств в обоснование правомерности владения имуществом в Русской Правде предусматривались две разновидности свидетелей. Первые именовались видоки. Ими нарекались свидетели, которые являлись очевидцами факта. Другая категория свидетелей - послухи. Они могли подтвердить определенные факты, 
поскольку слышали от кого-либо. По сути их показания на сегодняшний день можно было бы именовать косвенными доказательствами, поскольку они напрямую не имели сведений. Полученная ими информация была от «вторых рук», к примеру, от тех же видоков [3].

Подводя итог по данному нормативному акту, можно сделать вывод, что Русская Правда ставила институт защиты имущественных прав людей в зависимость от показаний свидетелей и в качестве гарантий их защиты предусматривала имущественную ответственность причинителя вреда по отношению к пострадавшей стороне.

Немаловажное значение на защиту имущественных прав на Руси оказала и Псковская судная грамота 1467 года. Ярким примером может служить защита прав собственника земельного участка. В ст. 9 Псковской судной грамоты было предусмотрено, что если лицо владеет земельным участком на протяжении 4 лет и на данный земельный участок на протяжении этого периода никто не предъявлял свои права, то данный земельный участок признавался собственностью его владельца при условии, если он представит в суде соседей (4 или 5), которые подтвердят его правомерное владение землей [5, с. 82]. Нововведением для существовавшего законодательства считается ст. 114 Псковской судной грамоты, предусматривающая признание сделки недействительной, если лицо на момент ее заключения находилось в состоянии алкогольного опьянения и не могло надлежащим образом руководить своими действиями $[5$, с. 95]. Из этого следует вывод, что в Псковской судной грамоте впервые возникает такой способ защиты прав, как признание сделки недействительной в связи с нахождением во время ее заключения в состоянии алкогольного опьянения.

Следующими нормативными актами, которые оказали активное воздействие на институт защиты имущественных прав в России, стали Судебники от 1497 и 1550 годов. В Судебнике 1497 г. предусматривался особый вид доказательства в судах при заключении договора займа. В соответствии с ст. 55 Судебника 1497 г. если одно лицо брало у другого лица товар на продажу и в путешествии данный товар пришел в негодность, сгорел или кто-нибудь его изъял (рать или боярин), то данному человеку выдавалась полетная грамота с печатью князя [1, с. 135]. Данный документ выступал доказательством выбытия имущества у его владельца из обладания. Именно этот акт являлся основанием для возврата денежных средств за данный товар. Проценты и иные выплаты при этом не предусматривались. В отличие от Судебника 1497 г., в котором возникает судебная власть как самостоятельная ветвь власти, в Судебнике 1550 г. данный процесс укрепляется в связи с ограничением судебной власти наместников и усилением роли центральных и местных судов.

Ocобое значение для защиты имущественных прав имеет Соборное уложение 1649 года. В соответствии со ст. 196 и 197 главы 10 Соборного уложения 1649 г. положения о залоге слегка изменены, а именно: если залогодатель нарушил срок хранения товара, находящегося в залоге, то право собственности на указанную вещь переходило к залогодержателю. Отличительная форма имущественной ответственности была предусмотрена в отношении заложенного товара, если указанный товар являлся животным. Залогодержатель, в случае смерти этого животного в пределах срока хранения и при отсутствии своей вины, вправе был получить только половину от суммы займа, от уплаты другой половины долга залогодатель освобождался.

Особое проявление защиты имущественных прав было предусмотрено в ст. 251-253 Соборного уложения 1649 года. Это меры ответственности за составление заемной кабалы (договор займа) и за принуждение к совершению сделки [7, с. 91-92]. Форма ответственности: от битья кнутами до тюремного заключения на срок до полгода.

\section{Законодательство Российской империи об институте защиты имущественных прав}

На смену законодательству Древней Руси приходит законодательство Российской империи. И первым нормативным актом, повлиявшим на имущественные права людей, стал Указ о единонаследии 1714 года. Это был первый акт, который ограничил оборот недви- 
жимого имущества граждан. Так, согласно ст. 1 данного указа запрещалось продавать или закладывать недвижимое имущество [7, c. 152]. Однако законодательство того времени не запрещало, а даже предписывало передавать данное имущество по наследству от отца к сыну. По сути это был единственный способ, позволяющий сменить владельца данного имущества на законных основаниях и при этом ограничить количество судебных тяжб о праве на недвижимое имущество.

Следует отметить, что первым актом в России, который кодифицировал законодательство о судебной защите, является Воинский устав Петра I от 1715 года. В данном акте отдельно предусмотрен раздел «Краткое изображение процессов или судебных тяжеб». В нем рассматривались положения о подсудности дел (только по месту нахождения ответчика), положения об адвокатах (только при наличии уважительной причины отсутствия стороны-участницы судебного процесса), положения о доказывании (4 вида доказательств признание, свидетельские показания, письменные доказательства и присяга) и др. [1].

Большое влияние на современное законодательство в области защиты имущественных прав оказал Свод законов Российской империи от 1832 года. В этом акте законодатель подробным образом раскрыл институт собственности: имеется собственность государственная, родовая и наличная (спорная). Отличительная особенность наличной собственности заключалось в том, что к ней относились не только недвижимое имущество, но и движимое имущество, а также капиталы, что прямо вытекает из ст. 416 главы 3 раздела 1 книги 2 тома 10 Свода законов Российской империи от 1834 г. [4].

Следует отметить, что Свод законов Российской империи - это первый закон в России, где была проведена систематизация оснований для защиты нарушенных прав лица путем выплаты различных компенсаций. Это отчетливо видно из содержаний таких глав, как глава 6 (О праве вознаграждения за понесенный вред и убытки) и глава 7 (О праве судебной защиты по имуществам). Так, в главе 6 было предусмотрено справедливое и приличное вознаграждение за принудительное изъятие недвижимого имущества, в том числе при временном изъятии. Также следует обратить внимание, что в случае изъятия имущества для государственных нужд владелец также получал компенсацию в размере стоимости данного имущества либо, по согласованию с собственником, равное и однородное имущество. Размер вознаграждения определялся по достигнутому соглашению, а в случае недостижения соглашения - комиссией, образованной предводителем уездного дворянства.

Отдельное внимание следует обратить на главу 7 , в которой было предусмотрено, что в случае причинения ущерба пострадавшая сторона вправе предъявить иск в суд. Однако устанавливался предельный срок - в течение 10 лет. При этом не запрещалось оборонять имущество от самоуправства со стороны иных лиц.

\section{Законодательство СССР о способах защиты имущественных прав}

Исследуя законодательство России, необходимо обратить внимание и на советский период становления и развития института защиты имущественных прав граждан.

В ст. 59 Гражданского кодекса РСФСР 1922 г. предусматривалось, что собственник имел право производить розыск своего имущества и в случае установления его нахождения - истребовать его, а также потребовать возместить расходы, извлеченные в связи с использованием данного имущества. В случае если имеет место добросовестное владение чужим имуществом, то расходы взыскивались только за период, когда добросовестному владельцу стало известно о факте неправомерного владения указанным имуществом. В свою очередь, добросовестный владелец имел право истребовать от законного собственника имущества компенсации за совершенные им вынужденные расходы в отношении спорного имущества [6].

Следует отметить, что содержание нормы данной статьи фактически было отражено в Гражданском кодексе РСФСР 1964 года. Также положение данной статьи находит свое отражение и в современном Гражданском кодексе Российской Федерации.

Обращая внимание на Гражданский Кодекс РСФСР 1964 г. следует отметить, что 
данный нормативный акт представляет собой основу современного Гражданского кодекса РФ. В нем также имеются положения о защите гражданских прав (ст. 6), однако совокупность способов в нем намного уже, чем в действующем ГК РФ, несмотря на открытый перечень данных способов. При анализе данного нормативно-правового акта можно увидеть и положения о возникновении гражданских прав на имущество (ст. 4), и положения об установлении судом охраны имущества лица, безвестно отсутствующего (ст. 19), и положения о признании судом недействительной сделки при наличии определенных условий (ст. 48-58) и др. [2]. Поэтому смело можно утверждать, что в основании действующего Гражданского кодекса РФ от 1994 г. положен Гражданский кодекс РСФСР 1964 г. с изменениями, свойственными демократическому обществу.

\section{Выводы}

Таким образом, можно сделать вывод, что имущественные права граждан подлежали защите со времен основания Российского государства. Начиная со времен Древней Руси и заканчивая советским периодом имущество всегда находилось под пристальным вниманием законодателя и, как следствие, судебных органов. Именно институт защиты позволял собственникам имущества защитить свои права от противоправного вмешательства в их свободное владение, пользование и распоряжение имуществом. По этой причине данный институт всегда был, есть и будет актуальным и необходимым для дальнейшего применения, так как граждане всегда будут заинтересованы в защите своих прав от неправомерного воздействия.

\section{СПИСОК ЛИТЕРАТУРЫ}

1. Адъютант ру. - Электрон. текстовые дан. Режим доступа: http://adjudant.ru/regulations/171603.htm (дата обращения: 09.02.2018). - Загл. с экрана.

2. Гражданский кодекс РСФСР (угв. ВС РСФСР 11.06.1964) // Ведомости ВС РСФСР. - 1964. - № 24. Ст. 407.
3. Журнал научных публикаций аспирантов и докторантов. - Электрон. текстовые дан. - Режим доступа: http://jurnal.org/articles/2010/hist11.html (дата обращения: 09.02.2018). - Загл. с экрана.

4. Классика российского права. - Электрон. текстовые дан. - Режим доступа: http:/civil. consultant.ru/reprint/books/211/39.html\#img40 (дата обращения: 09.02.2018). - Загл. с экрана.

5. Маньковский, И. Ю. Хрестоматия по истории отечественного государства и права / И. Ю. Маньковский. - Барнаул : Изд-во Алт. ун-та, 2014. - Ч. 1. $246 \mathrm{c}$.

6. Постановление ВЦИК от 31.10 .22 «О введении в действие Гражданского кодекса РСФСР» (вместе с Гражданским кодексом РСФСР) // Известия ВЦИК. - 1922. - 12 нояб. (№ 256).

7. Титов, Ю. П. Хрестоматия по истории государства и права России / Ю. П. Титов. - М. : ПРОCПЕКТ, 1997. $-472 \mathrm{c}$.

\section{REFERENCES}

1. Adjutant.ru. URL: http://adjudant.ru/ regulations/1716-03.htm (accessed 9 February 2018).

2. Grazhdanskiy kodeks RSFSR (utv. VS RSFSR 11.06.1964) [The Civil Code of the RSFSR (Approved by the Supreme Council of the RSFSR on June 11, 1964)]. Vedomosti VS RSFSR, 1964, no. 24, art. 407.

3. Zhurnal nauchnykh publikatsiy aspirantov $i$ doktorantov [Journal of Scientific Publications of Postgraduate Students and PhD Students]. URL: http:/ /jurnal.org/articles/2010/hist11.html (accessed 9 February 2018).

4. Klassika rossiyskogo prava [Classics of the Russian Law]. URL: http://civil.consultant.ru/reprint/ books/211/39.html\#img40 (accessed 9 February 2018).

5. Mankovskiy I.Yu. Khrestomatiya po istorii otechestvennogo gosudarstva i prava. Ch. 1 [Anthology on the History of Russian State and Law. Part 1]. Barnaul, Izd-vo Alt. Un-ta, 2014. 246 p.

6. Postanovlenie VTsIK ot 31.10 .22 «O vvedenii v deystvie Grazhdanskogo kodeksa RSFSR» (vmeste s Grazhdanskim kodeksom RSFSR) [Decree of the AllRussian Central Executive Committee of October 31, 1922 'On the Implementation of the Civil Code of the RSFSR' (along with the Civil Code of the RSFSR)]. Izvestiya VTsIK, 1922, November 12 (no. 256).

7. Titov Yu.P. Khrestomatiya po istorii gosudarstva i prava Rossii [Anthology on the History of Russian State and Law]. Moscow, Prospekt Publ., 1997. $472 \mathrm{p}$. 


\section{ВОПРОСЫ ЧАСТНОПРАВОВОГО РЕГУЛИРОВАНИЯ}

\section{Information about the Author}

Teimuraz L. Pagava, Postgraduate Student, Department of Civil Law Disciplines, Volgograd Institute of Management - Branch of Russian Presidential Academy of National Economy and Public Administration, Gagarin St., 8, 400131 Volgograd, Russian Federation, teymuraz94@rambler.ru.

\section{Информация об авторе}

Теймураз Леванович Пагава, аспирант кафедры гражданско-правовых дисциплин, Волгоградский институт управления - филиал Российской академии народного хозяйства и государственной службы при Президенте Российской Федерации, ул. Гагарина, 8, 400131 г. Волгоград, Российская Федерация, teymuraz94@rambler.ru. 